\title{
Review on South Korea-United States Trade Relations: The Significance of America First's Doctrine
}

\author{
Demeiati Nur Kusumaningrum ${ }^{1}$ \\ International Relations Department ${ }^{1}$ \\ Faculty of Social and Political Sciences, University of Muhammadiyah Malang ${ }^{1}$ \\ demeiati.nk@umm.ac.id ${ }^{1}$ \\ Septian Nur Yekti² \\ Alumni of Global Trade Diplomacy, Graduate Studies of International Relations \\ Department $^{2}$ \\ Faculty of Social and Political Sciences, University of Gadjah Mada² \\ dyahwakil1@gmail.com²
}

\begin{abstract}
ABSTRAK
Pemerintahan Amerika Serikat di era Presiden Donald Trump merilis beberapa kebijakan yang bertujuan menguatkan kembali kepemimpinan Amerika ke arena politik dunia dalam bidang ekonomi dan keamanan. Melalui doktrin politik luar negeri - America First, Trump mengemukakan kebijakan ekonomi yang ditargetkan untuk menghemat pendapatan, menciptakan lapangan kerja bagi orang Amerika, dan mendorong merestrukturisasi perekonomian nasional. Tulisan ini bertujuan menjelaskan implikasi doktrin America First pada hubungan perdagangan AS dengan Korea Selatan. Mengacu pada sejarah hubungan perdagangan A.S., sistem pasar bebas telah menjadi prioritas pemerintah dalam negosiasi internasional, baik melalui perjanjian bilateral maupun multilateral. Pemerintah A.S. meyakini Korea Selatan telah keluar dari semangat perdagangan bebas yang telah disepakati oleh kedua negara. Sejak implementasi Korus FTA hingga tahun 2017, Korea Selatan dianggap telah mengadopsi pola kebijakan yang tidak sesuai dengan poin-poin kesepakatan. Pada bulan Maret 2016, Ketua Senat dari Komisi Keuangan mengirim surat kepada Duta Besar Korea Selatan untuk membahas implementasi komitmen terhadap aliran data, transparansi dan prediktabilitas harga, dan penggantian produk farmasi dan alat kesehatan, serta kemungkinan perusahaan AS berinvestasi dan beroperasi dengan perusahaan Korea Selatan. Proposal untuk negosiasi ulang disetujui oleh Korea Selatan pada Oktober 2017, yang setuju untuk mengadakan diskusi untuk modifikasi dan amandemen serta memenuhi prosedur domestik yang diperlukan pada bulan Desember 2017.
\end{abstract}

Kata kunci: America First, Korea Selatan, Negosiasi, Politik Luar Negeri, Perdagangan 


\section{ABSTRACT}

The United States under President Donald Trump administration is marked by several government policies aimed at returning U.S. leadership to the world political arena in both the economic and security fields. He argues that economic policy through the doctrine of America First will save income and create jobs for Americans and will help restructure the U.S. economy. This paper describes the impact of America First's doctrine on U.S. trade relations with South Korea. Referring to the history of U.S. trade relations, the free market system has become a priority in international negotiations, both through bilateral and multilateral agreements. It examines South Korea has come out of the spirit of free trade agreed by the two countries. Since the implementation of Korus FTA until 2017, South Korea has adopted a policy pattern that initially did not comply with the point of agreement. In March 2016, the senate head of the financial commission sent a letter to the South Korean ambassador discussing the implementation of commitments to data flow, transparency and predictability of pricing and reimbursement of pharmaceutical products and medical devices, and the possibility of U.S. companies investing and operating with South Korea companies. The proposal for renegotiation was approved by South Korea in October 2017, which agreed to hold discussions for modification and amendment and fulfill the necessary domestic procedures in December 2017.

Keywords: America First, Foreign Policy, Korea, Negotiation, Trade

\section{Introduction}

The U.S. and South Korea has strategic partnership in security and economic sectors. The United States involvement in politics in the East Asia region is expected to maintain stability of Korea Peninsula. It deals with the response to Russia dan China's policies which did not reach North Korea consideration to stop nuclear program (Kusumaningrum, 2018b). The South Korea-United States Free Trade Agreement (KORUS FTA) was initiated in 2006 and signed in 2007 under the administration of President Bush and Roh Moo-hyun (Lester, Manak, \& Hwa, 2019). However, this FTA was only approved by the U.S. Congress in 2011 through the H.R. 3080 decree and followed by an exchange of letters between the Obama administration and Lee Myung-bak which effectively made several modifications to the initial agreement, related to the trade in automotive and agricultural products. In March 2012, the U.S.South Korean FTA came into force. The initiation of the U.S.-South Korean FTA was influenced by the position of China which was listed as Korea's main trading partner replacing the U.S. position in 2003. Previously, in the mid-2000s, this position was taken over by Japan. Moreover, in the same time period, Japan and the 28 member 
states of the European Union surpassed the U.S. as the second largest trading partner of South Korea (Manyin, Chanlett-Avery, Nikitin, Williams, \& Corrado, 2017).

Based on the economic statistics of trade, after the enactment of the FTA, the U.S. return to be South Korea major economic partner. In 2013, the U.S. was the largest supplier and South Korean foreign direct investment (FDI) host country. In 2016, total trade in goods and services between the two countries have reached amount \$ 145 billion. It signed the South Korea as the seventh largest U.S. trading partner. Based on trade of goods, the U.S. was South Korea's second largest trading partner and the third largest source of imports in 2016.

Total trade in goods and services between the two countries is growing. U.S. exports increased from $\$ 61.9$ billion in 2011 to $\$ 63.9$ billion in 2016. Imports also increased from 67.3 billion to 81.4 billion in the same period. FDI between the two countries is also experiencing growth, with South Korea's FDI stock more than doubling, growing from \$ 19.9 billion in 2011 to $\$ 40.1$ billion in 2015 (the most recent data available). U.S. FDI in South Korea experienced moderate growth from \$ 28.1 billion to \$34.6 billion (Manyin et al., 2017).

The OEC show the 2017 economic performance of the South Korea as the 5th biggest exporter in the world (Simoes, 2017). The most recent export products are integrated circuits, refined petroleum, passenger and cargo ships, and vehicle parts, using the 1992 revision of the HS (Harmonized System) classification. The top of export destinations are China, United States, Vietnam, Hong Kong, and Japan. Whereas, the top imports of South Korea are Crude Petroleum $(\$ 56 \mathrm{~B})$, Integrated Circuits $(\$ 38.6 \mathrm{~B})$, Petroleum Gas $(\$ 17.3 \mathrm{~B})$, Photo Lab Equipment $(\$ 13.7 \mathrm{~B})$ and Coal Briquettes (\$13.3B). It comes from China, Japan, United States, Germany, and other Asia countries. Dealing with the existence of China and Japan as the potential economic relations with South Korea and the internationalization of U.S. foreign policy, the study analyzes the impact of America First Doctrine to Korea and U.S. trade relations.

This paper highlights the United States administration on the era of President Donald Trump that popular with the Doctrine of America First. Donald Trump is known as a nationalist American president. The media mentioned the several strict U.S. policies to foreign countries including restrictions on Muslim immigrants, border controls, and trade protectionism which poses challenge to international politics. President Trump's economic policy plan for 2017-2021 is ambitious for making 'America Great Again' known as the 'America First' foreign policy doctrine (Al Syahrin, 2018; Amadeo, 2018; Ettinger, 2018; Sachs, 2018; von Daniels, 2018a). President Trump believes that economic policy through the doctrine of America First will save income and create jobs for Americans and will help restructure the U.S. economy. 
In dealing with the U.S. trade balance deficit, President Trump focuses on protecting national industries from global competition. On January 23, 2017, the U.S. withdrew from the Trans-Pacific agreement which was considered less profitable. On September 2, 2017, the U.S. re-evaluated the Korus FTA agreement and demanded South Korea to import more U.S. trade commodities. On August 16, 2017, the U.S. raises import tariffs by 35 percent to Mexico as a result of renegotiating the NAFTA agreement. The application of the U.S. import tariffs on China which reached 25 percent has triggered instability of international trade (Amadeo, 2018). Trump's policy is claimed to have restored the U.S. economy better than President Obama's administration. It is strategy to decrease the rate of unemployment and trade balance deficit, to increase people's purchasing power, and generates overall growth of the American economy (Zandi, 2018). Therefore, this paper would like to describe the effect of America First Doctrine on trade relations between U.S. and Korea.

This paper collects content sourced from the publication of scientific papers on the agenda of the Korus FTA free trade agreement, the literature of research by experts based on scientific journals that discuss U.S. policy in President Trump's era, the application of the doctrine of America First and publications online and printed mass media that discusses the development of bilateral relations between the two countries. The content analysis is carried out by understanding the U.S. government's report related to the trade agreements of the two countries and interpreting the text contained in the document based on the basic assumptions of the theoretical foundation used as the analytical framework. The paper uses primary data sources in the form of U.S. and South Korean government reports based on the topic of discussion on the KORUS FTA free trade agreement. Meanwhile, secondary data sources were obtained from online and printed literatures based on research paper, working papers or scholar publications. The process of data collection is carried out by the method of literature study and document content analysis.

\section{Theoretical Framework: The Priority of U.S. Interest in Free Trade Agreement}

The author examines the case of KORUS FTA is reflected the theory from Susan Strange (1994) about the pattern of global political economy that entails American interest. In her book of "States and Markets", Strange's criticism originated from the weaknesses of the political economy based on the problems of the regime. Strange research asks to whom strengths those principles, norms, rules and decision-making processes are most reflected? Where do such sources of power come from: are they based on coercive power, on market success and on wealth, or on someone else's adherence to an ideology, belief system or set of ideas? Therefore, Strange directs attention to the four basic values of security, wealth, freedom and justice that influence policy makers as a result of international political economy. 
Structural power, on the other hand, is the power to shape and determine the structure of a global political economy in which other countries, their political institutions, their economic enterprises and (at least) their scientists and professional people must operate. This structural power, is an instrument or power to set the agenda for discussion or to design the rules of the regime and international customs which should regulate international economic relations (Strange, 1994, pp. 12-25).

The Strange's critics can be applied to the case of free trade agreement that preserve United States priorities. Based on the commitment of AUSFTA, the U.S. promote the higher standard of intellectual property right and motivates Australia legal protection compatible with the U.S. law and practices. Unfortunately, the U.S. sought to redesign national health care systems in its own image and had little success in Australia's case (Tully, 2016, pp. 397-399). The U.S. as the leading role in penetrating trade liberalization throughout the world has been started in 1990 with NAFTA (Cherniwchan, 2017; Ramoni-Perazz \& Orlandoni-Merli, 2012).

"In over a decade from 2000, FTAs between the U.S. and Singapore, Chile, Australia, Bahrain and Morocco, as well as regional trade agreements (RTAs) between the U.S. and five countries of Central America and the Dominican Republic are generally extended based on the NAFTA template. Meanwhile, its partner countries are gradually extending the U.S. FTA template to the outside." (Dong \& Su, 2016, p. 8)

NAFTA promoted the first generation of the high-standard Free Trade Agreement (FTA) that emphasizing provisions on competition, industrial standards, intellectual property and environment. The U.S. gained mutual partnership with Korea under Korus FTA and promoting trade liberalization in Asia-Pacific region by RCEP and Trans-Pacific Partnership (Dong \& Su, 2016; Park, 2017).

The U.S.-South Korea FTA applies a tariff schedule whereby the FTA can reduce tariffs on goods and services gradually, even up to $0 \%$ or free of tariffs. The tariff reduction is carried out by considering the sectors and commodities that are least sensitive to affect the economies of the two countries to the most sensitive. Since implementation until $2017,82 \%$ of U.S. products and $80 \%$ of South Korean products are free of tariffs. This has increased the number of tariff-free products between the two countries where before the implementation of the FTA only $38 \%$ of U.S. products and $13 \%$ of South Korean products were tariff-free. In the 10 years of the agreement, it is estimated that the percentage of U.S. and South Korean products that are free of tariffs will reach $99 \%$ and $98 \%$, respectively, with the elimination of tariffs for sensitive products occupying the longest period order.

In 2017, the sixth round of tariff reductions has been carried out. To date, the FTAs of the two countries have reached the highest standards, including commitments to 
ensure the ability of financial services companies to transfer data between two countries, which is the beginning of a very agreed commitment on digital trading commitments in the Trans Pacific Partnership (TPP). Non-tariff barriers to trade in goods and services, as well as foreign investment have been and will continue to be reduced or eliminated under the FTA Korus. The third phase of opening the South Korean market for legal services, the commitment to allow U.S. companies to joint ventures in South Korea began to be effective from March 2017 (Manyin, ChanlettAvery, Nikitin, Williams, \& Corrado, 2017, p. 32).

Total trade in goods and services between the two countries has been growing. U.S. exports increased from US\$ 61.9 billion in 2011 to US $\$ 63.9$ billion in 2016 . Imports also increased from 67.3 billion to 81.4 billion in the same time period. FDI between the two countries is also experiencing growth, with South Korea's FDI stock more than doubling, growing from US\$19.9 billion in 2011 to US\$ 40.1 billion in 2015 (the most recent data available). U.S. FDI in South Korea experienced moderate growth from US\$ 28.1 billion to US $\$ 34.6$ billion. They also stated that lower trade barriers in South Korea had increased exports of certain U.S. products. For example, beef exports have increased from US\$ 649 million in 2011 to US\$ 1 billion in 2016 as South Korea's beef import tariff drops from $40 \%$ to $24 \%$ and will continue to decline to $0 \%$ in 2026. U.S. auto exports have increased almost doubled from US $\$ 1$ billion in 2011 to US\$2.2 billion in 2016, so the U.S. exported more cars to South Korea than to Japan, despite the fact that Japan is a country with more than twice the population of South Korea and has a higher GDP per capita. South Korea's automotive tariffs were lowered from $8 \%$ to $4 \%$ after the Korus FTA was implemented and abolished in 2016. U.S. service exports have also risen to nearly US\$ 5 billion since the agreement was implemented (Manyin et al., 2017, pp. 32-33). From the perspective of U.S. interests, there are two reviews that contradict about the FTA. A review from Korus FTA supporters stated that the implementation of this agreement has increased competition and consumer choice in both countries, increased protection of U.S. intellectual property rights in South Korea, and increased transparency of the South Korean regulatory process (USTR, 2016).

On the other hand, the implementation of the KORUS FTA resulted the U.S. trade deficit against South Korea. Despite an increase in U.S. exports to South Korea for certain products, total U.S. exports to South Korea have not increased significantly since 2011, while U.S. imports from South Korea have grown by more than $20 \%$, causing the overall trade deficit to increase. The lion's share of the growing trade deficit was contributed by the automotive trade. U.S. imports of goods from South Korea increased by around \$ 13 billion from 2011 to 2016, with an increase in auto imports alone totaling nearly $\$ 9$ billion ( $\$ 12$ billion to $\$ 21$ billion). Under Korus FTA, $2.5 \%$ of tariffs for U.S. car imports remained in effect until January 2016, where tariffs for most cars were abolished. 
Furthermore, South Korea's commitment to implementing the Korus FTA is an important concern in the trade relations between the two countries. Based on the Congressional Research Service in May 23, 2017 some circles in the business community argued that South Korea was very slow in implementing aspects of the agreement and in some cases was not willing to comply with the spirit of the Korus FTA. In the early implementation of the KORUS FTA agreement, exporters complained about the severity of the required Korean custom service requirements that exceeded the original verification. A number of South Korean automotive regulations, including those related to emission standards and processes of improvement and information provision, have also sparked attention among U.S. companies regarding differences in treatment between imported products and domestic products (Manyin et al., 2017).

\section{The Significance of America First Doctrine}

\subsection{U.S. Government Evaluation of KORUS FTA Implementation}

The U.S. foreign policy in the Trump era influenced the evaluation of the KORUS FTA which tended to challenge U.S. economic interests. The doctrine of 'America First' motivates President Trump to ask the South Korean government to return to the commitment on free trade agreement of both countries. President Trump, who has held office since 2016, believes that Korus FTA has resulted the increasing of U.S. trade deficit against South Korea. During Trump's time, efforts to reduce the trade deficit were made. For example, on his visit to South Korea, the U.S. vice president, Mike Pence, expressed the focus of discussion on the U.S. trade deficit and continuing trade barriers on the South Korean market and stated to reform the FTA. President Trump in an interview in April 2017 stated that he would stop the agreement if the renegotiation was not successful, although it was not yet clear which points of agreement would be amended (Rucker, 2017).

'America First' is a phrase used to explain the President Donald Trump's approach for the U.S. practice in foreign policy dealing with state putting their own interests first as the mirror of human nature (Anton, 2019). It mentioned in the document of National Security Strategy of U.S. in December 2017,

"The American people elected me to make America great again. I promised that my Administration would put the safety, interests, and well-being of our citizens first. I pledged that we would revitalize the American economy, rebuild our military, defend our borders, protect our sovereignty, and advance our values. During my first year in office, you have witnessed my America First foreign policy in action. We are prioritizing the interests of our citizens and protecting our sovereign rights as a nation. America is leading again on the world stage. We are not hiding from the challenges we face. We are confronting them head-on and 
pursuing opportunities to promote the security and prosperity of all Americans.."(Trump, 2017)

The U.S. foreign policy orientation under President Donald Trump widely echoed as the "American First Doctrine".

In March 2016, the head of the Senate financial commission sent a letter to the South Korean ambassador discussing the implementation of commitments to data flow, transparency and predictability of pricing and reimbursement of pharmaceutical products and medical devices, and the possibility of U.S. companies to invest and operate with South Korean companies (Williams, Jurenas, \& Platzer, 2014). The 2017 United States Trade Representative (USTR) report states that industry groups claim that the Korean Fair Trade Commission (KFTC), an institution implementing South Korea's competition, unfairly treats competition from foreign and domestic companies, thereby potentially violating non-discrimination treatment obligations in Korus FTA (USTR, 2016).

According to the U.S. government, South Korea has come out of the spirit of free trade agreed by the two countries. The multilateral trading system is an instrument of the interests of Western countries in the markets of developing countries. The development of the international trade system was in fact influenced by strong political consolidation between the countries involved even though in practice it did not always implement the principles contained in the GATT articles as a whole.

The multilateral trading system derived from GATT regulations includes: 1) the principle of Non-discrimination, among others, in Articles I and III. These articles mention the concept of the principle of Most-Favored-Nations, which emphasizes that when a state gives privileges to reduce trade tariffs for a particular country, then the other partner countries must be treated equally; 2) Elimination of quota and nontariff barriers, among others, in Article XI. This article emphasizes the reduction or even the elimination of quota systems and non-tariff policies that are hampering international trade; 3) Methods for Reducing Trade Barriers, including Article XXVIII and XIX. In these articles the multilateral cooperation and political negotiations between countries are explained to jointly implement the mechanism of reducing tariffs and trade barriers; and 4) Other regulations in the 'commercial consideration' scheme that implicitly support the implementation of the free trade system, which seeks to explain the position between free markets and government intervention (Winham, 2005).

Referring to the history of U.S. trade relations, the free market system has become a priority in international negotiations, both through bilateral and multilateral agreements. This is consistent with the work of Thi \& Nguyen (2014), where free trade is an implementation of U.S. political ideology that upholds democracy and a 
liberal economy. The free market system is a recipe for the U.S. government to develop domestic economic potential as well as strengthening diplomatic relations between its partner countries (Baier \& Bergstrand, 2004; Goyal \& Joshi, 2006; Hanson, 2003; Kusumaningrum, 2018; Levy, 1997; Perry \& Berry, 2016; Sri, 2014). For the U.S. government, adherence to free trade agreements is not only a political instrument but also a 'good will' that is able to restore confidence (confidence building) to its alliance partners. Therefore, the U.S. trade balance deficit in the KORUS FTA scheme is considered as a momentum of declining U.S. confidence in its alliance - South Korea.

This paper understands that the U.S. effort to bring the Korean government to comply with the free trade scheme of the two countries is a manifestation of U.S. concern if South Korea becomes more independent and sovereign economically in East Asia so that the United States as the main partner. By considering the international political architecture in East Asia, the improvement of South Korea's economic relations with China made the U.S. rethink its economic economic interests towards South Korea. Based on international political architecture the U.S. and China tend to be competitors with each other (Bolt, Mavromatis, \& van Wijnbergen, 2019; Chong \& Li, 2019; Meltzer \& Shenai, 2019; von Daniels, 2018).

Based on data, the trade deficit under the Korus FTA scheme was not something new during the Trump administration. Since it came into force in 2012, there have been a number of South Korean policies that have reduced potential profits under the Korus FTA scheme, both breach of agreement and policies outside the Korus FTA scheme that have an impact on U.S.-South Korea trade. In 2014, for more than two years the FTA was enacted, the United States raised several significant issues related to the implementation of the agreement. Several working groups and committees were formed under Korus FTA and functioned as a place to monitor implementation. Thus, although at the beginning of the discussion regarding the achievement of the highest U.S.-South Korean economic relations standards after the enactment of FTA, the reality of its implementation did not go well as the points of agreement (USTR, 2014).

Some issues raised by U.S. officials and companies in 2014 included first, related to origin verification. The customs office of each trading partner implements procedures to determine whether imports from FTA partner countries meet criteria based on the rules of origin of the FTA and whether they meet the conditions for preferential treatment (ie lower tariffs or tariff-free). The U.S. exporter considers that the South Korean Customs Service (KCS) procedure implements excessive documentation requirements regarding the importation of U.S. products that are too burdensome and reduces the effectiveness of the FTA that previously removed tariffs on related commodities. Furthermore, the U.S. government questioned the decision to harm KCS on imports of U.S. origin products such as frozen orange juice concentrate, 
chemicals, cars, and other products. After the union issue was raised by the U.S., USTR and Custom and Border Protection (CBP) reported working with KCS to resolve this issue, and a positive decision can suggest some improvements have been made.

Second, related to express shipping packages. U.S. officials have also voiced that South Korea does not comply with Korus FTA requirements stating package delivery with a value of less than US $\$ 200$ is exempt from the requirements of formal entry documents, slowing delivery. Third, it is regarding data transfer which is an agreement that is considered to have high standards in FTA relations U.S.-South Korea. Korus FTA includes provisions that allow financial services companies operating in South Korea to process international data and new regulations in South Korea allowing such activities. However, U.S. companies have raised objections to the regulatory policies given regarding how to determine permitted offshoring activities. The South Korean government has agreed to review the implementation of its commitment on a quarterly basis on data transfers.

Fourth, related to the proposed automotive regulations. The South Korean government has proposed new regulations on car sales that are intended to provide incentives for consumers to buy cars with lower greenhouse gas emissions, generally closely correlated with engine size. U.S. carmakers are worried about the possibility of a tax penalty for consumers who buy cars with higher emission profiles, which they claim can effectively eliminate the tariff benefits they receive through FTA. The South Korean government then reviewed the proposed regulatory scheme, which will be implemented in January 2015.

Finally, related to pharmaceutical products and medical devices. U.S. industry has voiced concern over a new pricing regime for medicines in South Korea that they think could reduce the value of new drugs. The U.S. business group also claims that the patent relations system proposed by the South Korean government, which is needed under the FTA, could be biased in understanding for generic drug producers.

The U.S. industry also stated that factors not adequately covered in the FTA could negatively impact their ability to export to South Korea. For example, some groups, especially U.S. producers claim that South Korea has intervened in the international currency market to weaken the South Korean won relative to the U.S. dollar, thereby effectively raising the price of U.S. exports to the South Korean market (USTR, 2014). From the U.S. perspective, it can be understood that South Korea carries out policies that brought disadvantages to the U.S. economy.

\subsection{The U.S.- South Korea New Deals}

Faced these conditions, the U.S. under Trump's administration proposed renegotiations to revise the KORUS agreement so that the U.S. would not continue 
to experience a deficit (Williams, Canis, Hopkinson, \& Manyin, 2018). The proposal for renegotiation was approved by South Korea in October 2017, which agreed to hold discussions for modification and amendment and fulfill the necessary domestic procedures in December 2017. The negotiations proposed by the U.S. aim to achieve the following points: 1 ) Increase the outcomes of U.S. export opportunities and facilitating a two-way trade balance; 2) Resolution of important issues in implementation that continuously endanger or weaken the potential of U.S. exports; 3) Re-balance commitments at the rates needed to guarantee reciprocal conditions in general and mutually beneficial commitments under the agreement scheme; 4) Reducing and removing non-tariff barriers to exports of motorcycles and U.S.-made motorcycle components; 5) Increase other points to ensure the benefits of an agreement in order to directly support job creation in the U.S..

Through the agreement, the U.S. succeeded in reaching an amendment that was considered to be able to reduce the trade deficit and ensure the Korus FTA had a good impact on U.S. workers, farmers and businesspeople. These outcome points are first, regarding the U.S. truck rates, South Korea agreed that the U.S. would gradually phase out the elimination of tariffs for trucks until 2041, or a total of 30 years from the implementation of the KORUS FTA in 2012 (previously scheduled to be phased out in 2021).

The second point is for the growth of U.S. automotive exports. The KORUS FTA eliminated the $2.5 \%$ U.S. auto import tariff in 2016 . South Korea's $8 \%$ auto import tariff was reduced to $4 \%$ immediately and eliminated in 2016, and its $10 \%$ light truck tariff was immediately eliminated. Under KORUS, bilateral tariffs on virtually all auto parts immediately dropped to zero. From 2011 to 2017, U.S. auto and parts exports doubled to US $\$ 2.4$ billion, while U.S. imports increased by $55 \%$ to US $\$ 23.9$ billion (Manyin et al., 2017).

Second, harmonization of testing requirements. Exports of U.S. gasoline-engine vehicles will be able to demonstrate compliance with Korean emission standards using the same tests they do to demonstrate compliance with U.S. regulations, without additional or duplicative testing for the Korean market. Third, for recognition of the U.S. Standards for Car Parts, South Korea will recognize U.S. standards for car parts needed to service U.S. vehicles, and reduce the labeling burden for parts. Fourth, increase in CAFE standards. Korea will expand the amount of "eco-credit" available to help meet fuel economy and greenhouse gas requirements under current regulations, while also ensuring that future fuel economy targets will regulated by U.S. regulations taking into account and will continue to include softer targets for manufacturers selling small volumes of cars in Korea (Williams, Canis, Hopkinson, \& Manyin, 2018). 
The third point is for the improvement of Customs, South Korea will overcome old concerns with heavy and expensive verification procedures through the agreement of principles to verify the origin of exports under Korus FTA and form a working group to monitor and deal with future problems that arise. The last point is related to refunding pharmaceutical costs. In 2018, Korea will change its Premium Price Policy for Global Innovative Drugs to be consistent with Korea's commitment under Korus FTA to ensure non-discriminatory and fair treatment for U.S. pharmaceutical exports.

Based on these phenomena, it is realized that the United States government is trying to maintain its competitiveness in South Korea in the face of Seoul FTA negotiations with other major trading partners, including the European Union. For the South Korean government, Korus FTA is a mechanism to promote national economic reforms and also to gain greater access for Seoul to the U.S. market for car commodities and other manufactured goods (Williams et al., 2014).

As the remarks of President Donald Trump,

\begin{abstract}
"President Moon, I just want to tell you we've developed a great relationship on many different fronts. This one is on trade, but we're working very well on North Korea. A lot of very positive things are happening with Chairman Kim of North Korea. And you'll be hearing about that over the coming weeks. But I think some really, really important things are happening. As I said just a little while ago, we have an agreement to work out another summit. And we look forward to doing that. I'm going to be meeting with Chairman Kim in the not too distant future. The location is being worked on, the time is being worked on, and we'll be announcing it. As far as these negotiations, our two countries have set an example of friendship and cooperation for trade that rarely you see in this age. And I just want to tell you I'm very honored to be a part of it, and I'm honored to call you a friend. And I'm honored to say that the United States and South Korea have a great friendship together. Thank you very much." (Trump, 2018)
\end{abstract}

Through the agreement, the U.S. succeeded in reaching an amendment that was considered to be able to reduce the trade deficit and ensure that KORUS had a good impact on U.S. workers, farmers and business people (Camas, 2018; Campbell, 2018; Lester et al., 2019; Tankersley, 2018; Trump, 2018).

The free market system has become a priority of U.S. administration in international negotiations, both through bilateral and multilateral agreements. The U.S. government committed to the implementation of liberal economy to develop state capacities as well as strengthening diplomatic relations between its partner countries (Kusumaningrum, 2018; Perry \& Berry, 2016; Robinson, 2015).

For the U.S. government, adherence to free trade agreements is not only a political instrument but also a 'good will' that is able to restore confidence (confidence 
building) to its alliance partners. The U.S. trade balance deficit from the KORUS FTA scheme is considered as a momentum of declining U.S. confidence in its alliance South Korea. KORUS FTA's evaluation is evidence of the interests of the U.S. foreign policy under Donald Trump's administration which seeks to strengthen its influence in East Asia. By considering the improvement of South Korea's economic relations with China motivates the U.S. administration to re-assessment the KORUS FTA. Political scholars have realized that America and China have a large and influential economic power. Thus, the East Asian region became an area of political contestation between the two countries (Chung \& Choi, 2013; Herrero, 2019; Meltzer \& Shenai, 2019; von Daniels, 2018a).

\section{Conclusion}

This paper analyzed President Trump's foreign policy with the doctrine "America First" influencing the internalization of U.S. interests in its bilateral relations with South Korea. As a South Korean alliance in East Asia, the Trump administration prioritizes U.S. economic interests as compensation for U.S. support for South Korea over the Korean Peninsula conflict. Therefore, an evaluation of the free trade agreement between the two countries is an important negotiation agenda.

Based on U.S. foreign policy in the Donald Trump administration, the change in points after the renegotiation agreement with the South Korean government had an impact on first, changing tariff commitments by extending $25 \%$ of U.S. light truck fares in twenty years to 2041. Second, doubling the number of U.S. vehicle exports to South Korea which can be imported with U.S. safety standards (25,000 to 50,000 per producer per year), and clarifies South Korea's recognition of certain U.S. emissions and auto parts standards for U.S. exports. Third, replace the trade improvement chapter by adding transparency and reporting requirements including calculation of margin dumping. Fourth, change the investment chapter, including additions to the TPP, such as clarifying that public welfare can be considered in determining national treatment and that failure to meet investor expectations does not violate the minimum standard of treatment provisions. Fifth, ensure customs principles regarding verification of origin that are fast and risk-based. Sixth, change South Korea's Premium Pricing Policy for Global Innovative New Drugs to ensure it is consistent with KORUS's commitment. Finally, begin adding certain textile and apparel inputs to the KORUS supply shortlist, potentially allowing South Korea to use larger amounts of third-party inputs in some exports to the United States.

Based on analysis, since implementation of Korus FTA until 2017, South Korea has adopted a policy pattern that initially did not comply with the poin of agreement, then agreed to renegotiate with the U.S. for better implementation. After negotiations, South Korea again disobeyed, until during Trump's administration, the U.S. initiated to renegotiate an agreement by amending its points. South Korea agreed to amend 
the agreement as described above and with the amendment points that have been mentioned.

\section{Acknowledgements}

The authors send the gratitude to the people who have helped in the completion of this paper. Especially the University of Muhammadiyah Malang which has funded the author's research. In addition, thanks to colleagues in the Department of International Relations and students in international political economy classes who are always open to discussion activities and present interesting topics. The special appreciation deliver to Dr. Oman Sukmana, M.Si. as the peer-reviewer who enriched the authors with beneficial comments. 


\section{References}

Books

Manyin, M. E., Chanlett-Avery, E., Nikitin, M. B. D., Williams, B. R., \& Corrado, J. R. (2017). U.S. -South Korea Relations (R41481 No. 7-5700).

Sachs, J. D. (2018). A New Foreign Policy: Beyond American Exceptionalism. New York Chichester, West Sussex: Columbia University Press.

Strange, S. (1994). States and Markets (Second edition). London: Continuum.

Winham, G. R. (2005). The Evolution of The Global Trade Regime. In J. Revenhill (Ed.), Global Political Economy (pp. 89-90). New York: Oxford University Press

$\underline{\text { Journals }}$

Al Syahrin, M. N. (2018). Donald Trump dan Reorientasi Kebijakan Keamanan Amerika Serikat Terhadap Program Pengembangan Senjata Nuklir Korea Utara. Jurnal Ilmiah Hubungan Internasional, 97. https://doi.org/10.26593/jihi.v14i1.2717.97-111.

Baier, S. L., \& Bergstrand, J. H. (2004). Economic determinants of free trade agreements. Journal of International Economics, 64(1), 29-63. https://doi.org/10.1016/S0022-1996(03)00079-5.

Bolt, W., Mavromatis, K., \& van Wijnbergen, S. (2019). The Global Macroeconomics of a Trade War: The EAGLE Model on the U.S.-China Trade Conflict (January No. 623). SSRN Electronic Journal. Amsterdam. https://doi.org/10.2139/ssrn.3338903.

Cherniwchan, J. (2017). Trade liberalization and the environment: Evidence from NAFTA and U.S. manufacturing. Journal of International Economics, 105, 130-149. https://doi.org/10.1016/j.jinteco.2017.01.005

Chong, T. T. L., \& Li, X. (2019). Understanding the China-U.S. trade war: causes, economic impact, and the worst-case scenario. Economic and Political Studies, 7(2), 185-202. https://doi.org/10.1080/20954816.2019.1595328

Chung, J. H., \& Choi, M. (2013). Uncertain allies or uncomfortable neighbors? Making sense of China-North Korea Relations, 1949-2010. The Pacific Review, 26(3), 243264. https://doi.org/10.1080/09512748.2012.759262

Clark, S. E., Hawkes, C., Murphy, S. M. E., Hansen-Kuhn, K. A., \& Wallinga, D. (2012). Exporting obesity: U.S. farm and trade policy and the transformation of the Mexican consumer food environment. International Journal of Occupational and 
Environmental

Health,

$18(1)$

$53-64$.

https://doi.org/10.1179/1077352512Z.0000000007

Dong, Y., \& Su, Q. (2016). Unveiling the Trans-Pacific partnership: An analysis of the full text. International Organisations Research Journal, 11(4), 7-18. https://doi.org/10.17323/1996-7845-2016-04-162

Ettinger, A. (2018). Trump's National Security Strategy: "America First" meets the establishment. International Journal: Canada's Journal of Global Policy Analysis, 73(3), 474-483. https://doi.org/10.1177/0020702018790274

Goyal, S., \& Joshi, S. (2006). Bilateralism and free trade. International Economic Review, 47(3), 749-778. https://doi.org/10.1111/j.1468-2354.2006.00395.x

Kusumaningrum, D. N. (2018a). The United States and Latin America Regional Cooperation: Organization of American States (OAS). JURNAL SOSIAL POLITIK, 4(1), 149-167. https://doi.org/10.22219/SOSPOL.V4I1.5566.G5329

Kusumaningrum, D. N. (2018b). Tragedi Cheonan 2010: Dilema Keamanan Asia Timur. Jurnal Studi Diplomasi Dan Keamanan, 10(1). Retrieved from http://jurnal.upnyk.ac.id/index.php/jsdk/article/view/2596

Levy, P. I. (1997). A Political-Economic Analysis of Free-Trade Agreements. American Economic Review, 87(4), 506-519. https://doi.org/10.2307/2951361

Park, S. C. (2017). RCEP versus TPP with the trump administration in the USA and implications for east Asian economic cooperation. Entrepreneurial Business and Economics Review, 5(4), 135-152. https://doi.org/10.15678/EBER.2017.050406

Perry, D. M., \& Berry, K. A. (2016). Central American integration through infrastructure development: A case study of Costa Rican hydropower. Regions \& Cohesion, $6(1)$, 96-115. https://doi.org/http://dx.doi.org/10.3167/reco.2015.060105

Ramoni-Perazz, J., \& Orlandoni-Merli, G. (2012). Nafta and the Usa-Colombia Fta: Learning From the Past? Suma de Negocios, 3(2), 37-52.

Robinson, W. I. (2015). The transnational state and the BRICS: a global capitalism perspective. Third World Quarterly. https://doi.org/10.1080/01436597.2015.976012

Tully, S. R. (2016). Free Trade Agreements with the United States: 8 Lessons for Prospective Parties from Australia's Experience. British Journal of American Legal Studies. https://doi.org/10.1515/bjals-2016-0014 


\section{Internet Sources}

Amadeo, K. (2018). President Donald Trump's Economic Plan. Retrieved January 3, 2019, from https://www.thebalance.com/donald-trump-economic-plan-3994106.

Anton, M. (2019, April 20). The Trump Doctrine. Foreign Policy. Retrieved from https://foreignpolicy.com/2019/04/20/the-trump-doctrine-big-think-america-firstnationalism/.

Camas, A. (2018). Trump Signs Revised United States-Korea Free Trade Agreement (KORUS). Worldwide ERC. Retrieved from

https://www.worldwideerc.org/news/trump-signs-revised-united-states-korea-freetrade-agreement-korus/.

Campbell, A. F. (2018, September 25). KORUS: Trump's new trade deal with South Korea, explained - Vox. Vox. Retrieved from https://www.vox.com/2018/9/24/17883506/trump-korea-trade-deal-korus.

Hanson, G. H. (2003). What Has Happened To Wages In Mexico Since NAFTA? Implications For Hemispheric Free Trade (March No. 9563). Massachusetts. Retrieved from http://www.nber.org/papers/w9563

Herrero, A. G. (2019). Europe in the Midst of China-U.S. Strategic Economic Competition: What are the European Union's Options? Retrieved from https://www.businessinsider.com/huawei-cfo-arrest-who-is-meng-wanzhou-2018$12 ? \mathrm{r}=\mathrm{U} . \mathrm{S} . \& \mathrm{IR}=\mathrm{T}$

Lester, S., Manak, I., \& Hwa, K. (2019). Trump's First Trade Deal: The Slightly Revised Korea-U.S. Free Trade Agreement | Cato Institute. Cato Institute. Retrieved from https://www.cato.org/publications/free-trade-bulletin/trumps-firsttrade-deal-slightly-revised-korea-us-free-trade

Meltzer, J. P., \& Shenai, N. (2019). The U.S.-China Economic Relationship: A Comprehensive Approach. Retrieved from

https://www.brookings. edu/research/the-us-china-economic-relationship-acomprehensive-approach/

Rucker, P. (2017, April 28). Trump: 'We may terminate' U.S.-South Korea trade agreement. The Washington Post. Retrieved from

https://www.washingtonpost.com/politics/trump-we-may-terminate-us-southkorea-trade-agreement/2017/04/27/75ad1218-2bad-11e7-a616d7c8a68c1a66 story.html?noredirect=on\&utm term $=.2 \mathrm{fb} 447 \mathrm{~b} 5 \mathrm{~b} 8 \mathrm{~d} 5$ 
Simoes, A. (2017). OEC - South Korea (KOR) Exports, Imports, and Trade Partners. Retrieved November 15, 2019, from https://oec.world/en/profile/country/kor/\#Imports

Sri, P. (2014). Kepentingan Amerika Serikat dalam Korea-U.S. Free Trade Agreement (KORUS FTA). Universitas Muhammadiyah Malang. Retrieved from http://eprints.umm.ac.id/25771/1/jiptummpp-gdl-sripangest-38555-2-bab1.pdf

Tankersley, J. (2018, September 24). Trump Signs Revised Korean Trade Deal The New York Times. The New York Times. Retrieved from https://www.nytimes.com/2018/09/24/us/politics/south-korea-trump-tradedeal.html

Trump, D. (2017). National Security Strategy of the United States of America. Retrieved from https://www.whitehouse.gov/wp-content/uploads/2017/12/NSSFinal-12-18-2017-0905.pdf

Trump, D. (2018, September 24). Remarks by President Trump and President Moon of the Republic of Korea at U.S.-Korea Free Trade Agreement Signing Ceremony. U.S. Government. Retrieved from https://www. whitehouse.gov/briefingsstatements/remarks-president-trump-president-moon-republic-korea-u-s-koreafree-trade-agreement-signing-ceremony/

USTR. (2014). Korea. In 2014 National Trade Estimate Report on Foreign Trade Barriers (pp. 207-216). Retrieved from https://ustr.gov/sites/default/files/2014 NTE Report on FTB.pdf

USTR. (2016). Fact Sheet: Four Year Snapshot: The U.S.-Korea Free Trade Agreement. Retrieved October 15, 2018, from https://ustr.gov/about-us/policyoffices/press-office/fact-sheets/2016/March/Four-Year-Snapshot-KORUS

von Daniels, L. (2018a). U.S. Government Trade Policy. Trump's 'America First' Policy Puts Pressure on the EU. Retrieved from https://css.ethz.ch/content/dam/ethz/special-interest/gess/cis/center-forsecurities-studies/resources/docs/SWP 2018C36 dns.pdf

Williams, B. R., Canis, B., Hopkinson, J., \& Manyin, M. E. (2018). U.S.-South Korea (KORUS) FTA Updated December 28, 2018. Retrieved from https://fas.org/sgp/crs/row/IF10733.pdf

Williams, B. R., Jurenas, R., \& Platzer, M. D. (2014). The U.S.-South Korea Free Trade Agreement (KORUS FTA): Provisions and Implementation. Retrieved from https://fas.org/sgp/crs/row/RL34330.pdf

Zandi, M. (2018, December 27). Trump's misplaced economic policies could sink the U.S. economy next year. CNN Business. Retrieved from https://edition.cnn.com/2018/12/27/perspectives/trump-stock-market-economyforecast/index.html 